\title{
Áhrif endurhæfingar á prek, holdafar og heilsueflandi hegðun hjartasjúklinga með sykursýki af tegund 2
}

\author{
Karl Kristjánsson ${ }^{1}$ læknir, Magnús R. Jónasson ${ }^{1}$ læknir, Sólrún Jónsdóttir ${ }^{1}$ sjúkrapjálfari, Hjalti Kristjánsson ${ }^{1}$ lífeðlisfræðingur, \\ Marta Guðjónsdóttir ${ }^{1,2}$ lífeðlisfræðingur
}

\section{ÁGRIP}

Inngangur: Sykursýki af tegund 2 er vel pekktur áhættupáttur hjarta- og æðasjúkdóma. Mikilvægt er að próa og meta leiðir til að draga úr áhættupáttum og bæta heilsu peirra hjartasjúklinga sem jafnframt hafa sykursýki. Efniviður og aðferðir: Framskyggn hóprannsókn meðal sjúklinga með sykursýki af tegund 2 sem komu til hjartaendurhæfingar á Reykjalundi frá 1/7 2011 til 31/12 2012. Algengi sykursýki af tegund 2 meðal sjúklinga í hjartaendurhæfingu var borið saman við algengi í rannsókn Hjartaverndar. Rannsóknarhópurinn með sykursýki var borinn saman við aðra sjúklinga í hjartaendurhæfingu á sama tímabili hvað varðar holdafar og prek fyrir og eftir meðferð. Fylgst var með lífsháttabreytingum rannsóknarhópsins í priggja og sex mánaða eftirfylgd, meðal annars varðandi reykleysi, hreyfivenjur og göngugetu.

Niðurstöður: Algengi sykursýki af tegund 2 í hjartaendurhæfingu var miklu meira en í samanburðarbýði Hjartaverndar. Rannsóknarhópurinn var pyngri, hærra hlutfall hans hafði offitu, mittismál var meira og prek minna, miðað̃ við aðra hjartasjúklinga. Breyting varð hjá báđum hópunum á meðferðartímanum, peir léttust, mittismál minnkaði, en pó jókst prek minna hjá rannsóknarhópnum. Eftir 6 mánuði hafði pyngd og blóðsykur rannsóknarhópsins farið í fyrra horf, en mittismál var minna og hópurinn hélt aukinni hreyfingu og göngugetu miðað við upphaf meðferðar. Ályktun: Sykursýki af tegund 2 er algengari í hjartaendurhæfingu en almennu pýði á Íslandi. Hjartasjúklingar með sykursýki eru að jafnaði feitari og með heldur lélegra prek og minni svörun við pjálfun en aðrir hjartasjúklingar. Eftirfylgd í 6 mánuði sýndi hins vegar að aukning varð í reglulegri hreyfingu meðal hópsins og pað endurspeglaðist í bættri göngugetu.
${ }^{1}$ Hjartasviði Reykjalundar, Endurhæfingarmiðstöðvar SíBS, ${ }^{2}$ Lifeðlisfræðistofnun Háskóla Íslands

Fyrirspurnir: Karl Kristjánsson karlk@reykjalundur.is

\section{Inngangur}

Á síðustu áratugum hefur peim fjölgað mjög sem glíma við offitu hér á landi eins og víða um heim. Samtímis pví hefur orðið mikil aukning á sykursýki af tegund 2, en talið er að tilfelli sjúkdómsins í heiminum hafi um pað bil tvöfaldast á síðustu 20 árum. ${ }^{1}$ Rannsóknir Hjartaverndar á heilsufari Íslendinga hafa sýnt fram á sömu próun á Íslandi með mikilli aukningu á ofpyngd, offitu og sykursýki af tegund 2. Sérstaklega er breytingin áberandi meðal karlmanna, en algengi sykursýki af tegund 2 hjá 45-64 ára einstaklingum á Íslandi árið 2007 var 6,3\% hjá körlum en um 3,0\% hjá konum. $^{2}$

Niðurstöður faraldsfræðilegra rannsókna hafa líka sýnt að peir einstaklingar sem hafa sykursýki af tegund 2 hafa allt að 2-3 falt auknar líkur á að fá hjarta- og æðasjúkdóma. ${ }^{3,4}$ Má pví gera ráð fyrir að meðal peirra sem koma til meðferðar og endurhæfingar vegna hjartasjúkdóma sé algengi sykursýki talsvert meira en almennt gerist.

Grunnpættir í meðferð sykursýki af tegund 2 eru fræðsla um mataræði og reglubundin hreyfing, auk lyfjameðferðar. ${ }^{5}$ Pó gagnsemi lyfjameðferðar við sykursýki sé vel pekkt hafa nýlegar rannsóknir sýnt fram á vissar takmarkanir hennar til að ráða við afleiðingar sykursýki af tegund 2. Jafnvel getur áköf lyfjameðferð í sumum tilvikum ýtt undir pyngdaraukningu og aukið tíðni blóðsykurfalla. ${ }^{6}$ Pví parf að próa og meta aðferðir til að meðhöndla pessa gerð sykursýki með breyttum lífsstíl til langs tíma. Pað er pví mjög aðkallandi viðfangsefni að komast að pví hvernig pessum pætti meðferðarinnar verður best háttað hér á landi á næstu árum til að ná sem bestum árangri.

Rannsókn pessi var gerð á hjartasviði Reykjalundar, en skipulögð hjartaendurhæfing á stigi II hefur farið fram par frá árinu 1982. Meirihluti peirra sem koma pangað til endurhæfingar eru með kransæðasjúkdóm, eða um $70 \%$, en helstu ástæður fyrir tilvísun sjúklinga í hjartaendurhæfingu eru pjálfun og aðlögun, meðal annars eftir kransæðaaðgerðir, hjartaáföll og kransæðavíkkanir en einnig eftir lokuaðgerðir og vegna hjartabilunar.

Markmið pessarar rannsóknar var í fyrsta lagi að kanna framvirkt algengi sykursýki af tegund 2 í hópi peirra einstaklinga sem komu til hjartaendurhæfingar á stigi II á Reykjalundi og bera saman við almennt úrtak Hjartaverndar frá sama tímabili.

Í öðru lagi að bera saman árangur endurhæfingar sykursjúkra hjartasjúklinga og annarra hjartasjúklinga.

Fylgst var með hugsanlegri áhættu við pjálfun hjartasjúklinga með sykursýki af tegund 2, sérstaklega með tilliti til mögulegra blóðsykurfalla eða annarra áfalla. Sambærileg rannsókn á hjartaendurhæfingu sykursjúkra hefur ekki verið gerð áður hér á landi. 


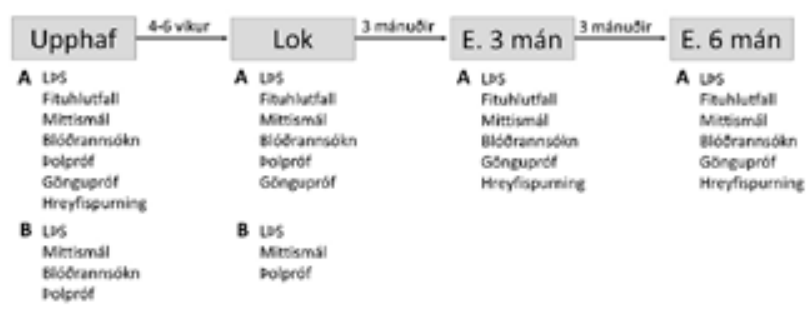

Mynd 1. Myndin sýnir pær mælingar sem gerðar voru við upphaf og lok meðferðar og í endurkomu (E.) eftir 3 og 6 mánuði. LPS er líkamspyngdarstuðull. A sýnir pær mælingar sem hjartasjúklingar með sykursýki af tegund 2 fóru i (rannsóknarhópurinn). B sýnir pær mælingar sem allir fóru í sem voru i hjartaendurhæfingu á rannsóknartímabilinu og notaðar voru til samanburðar við rannsóknarhópinn.

\section{Efniviður og aðferðir}

Rannsókn pessi var framskyggn hóprannsókn par sem öllum peim sjúklingum sem hófu hjartaendurhæfingu á Reykjalundi á 18 mánaða tímabili frá 1/7 2011 til 31/12 2012 og voru með sykursýki af tegund 2, var boðin pátttaka í rannsókninni og sampykktu allir.

Sykursýki var skilgreind til staðar hjá peim sem tóku sykursýkislyf eða höfðu pekkta greiningu á sykursýki af tegund 2. Einnig var sykursýki greind samkvæmt hefðbundnum skilmerkjum ef fastandi blóðsykur var $\geq 7,0$ mmól/L við tvö tilvik, eins og miðað er við í klínískum leiðbeiningum landlæknis. ${ }^{7}$

Endurhæfing hjartasjúklinga með sykursýki var eins og annarra hjartasjúklinga og í jafn langan tíma, nema peir fyrrnefndu fengu sérstaka sykursýkisfræðslu á meðferðartímanum og komu í endurkomur vegna rannsóknarinnar premur og sex mánuðum eftir að meðferð lauk. Endurhæfing á stigi II er að jafnaði 4 vikur, en í sumum tilvikum 5-6 vikur, sérstaklega hjá einstaklingum með hjartabilun. Í henni felst markviss styrk- og polpjálfun, sálræn og félagsleg aðlögun, meðferð áhættupátta og fjölpætt fræðsla. Pjálfunin er einstaklingsmiðuð, ákefð pjálfunar byggir á sjúkdómsgreiningu, sögu og niðurstöðum úr polprófi við komu. Hver einstaklingur er að jafnaði í 3-4 pjálfunartímum á dag (um pað bil 90-150 mín) alla virka daga með stigvaxandi álagi yfir tímabilið. ${ }^{8}$ Allir sjúklingar með sykursýki fengu sérstaka fræðslu, meðal annars um æskilegt mataræði.

Mynd 1 sýnir yfirlit yfir pær mælingar sem gerðar voru við upphaf og lok endurhæfingar og í endurkomum.

Til að meta hvort munur væri á rannsóknarhópnum og öðrum peim sem voru í hjartaendurhæfingu á sama tíma, voru bornar saman niðurstöður polprófa, blóðprufa og mælinga á líkamspyngdarstuðli (LPS) sem gerðar voru við upphaf og lok endurhæfingar. LPS var reiknaður út frá mældri hæð í cm og vigtaðri pyngd í kg. Fituhlutfall var mælt með rafleiðnimæli að morgni dags (BIA 310 Bioimpedance analyser, Seattle Washington USA). Mittismál var mælt samkvæmt leiðbeiningum frá Hjartavernd par sem ummál mittis er mælt milli mjaðmakambs og neðstu rifja í láréttu plani, beint á húð með sjúkling standandi. Blóðsýni voru tekin fastandi að morgni dags. Mælingar voru gerðar samdægurs á blóðrannsóknarstofu Landspítala á eftirfarandi: S-glúkósi, s-HDL, spríglýseríð, og b-HbA1c, nema við lok meðferðar pegar aðeins var mældur s-glúkósi. Polpróf var gert á prekhjóli (VIA sprint 150P, Ergoline, Pýskaland) við upphaf og lok meðferðar, par sem við-

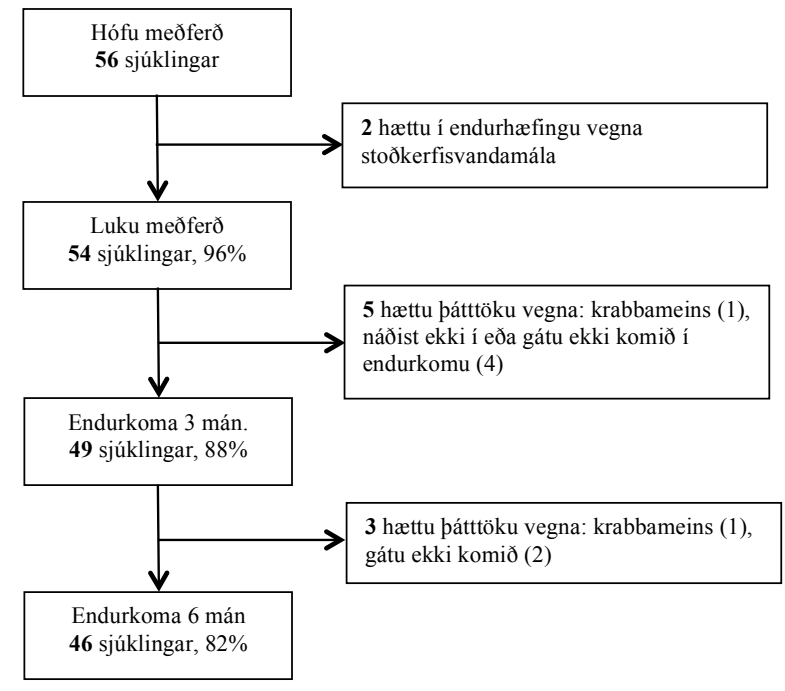

Mynd 2. Yfirlit yfir mætingu og brottfall hjartasjúklinga með sykursýki af tegund 2 (rannsóknarhópurinn).

komandi hjólaði við stigvaxandi álag (6-12 mínútur) par til hann gafst upp eða prófið var stoppað af læknisfræðilegum ástæðum. Fylgst var með 12 leiðslu hjartarafriti (CS- 200, Schiller, Baar, Sviss) og blóðprýstingur var mældur á mínútufresti eða oftar. Skráð voru hámarksafköst sjúklings á hjólinu (í vöttum) og reiknað út prek viðkomandi (hámarksafköst/líkamspyngd; v/kg). Göngupróf voru stöðluð 6 mínútna göngupróf ${ }^{7}$ par sem viðkomandi gekk eins langa vegalengd og hann gat á 6 mínútum. Sex mínútna göngupróf er ekki hámarkspolpróf, en er góður mælikvarði til að meta prek og endurspegla getu við athafnir daglegs lífs. Рað er pekkt að mikil fylgni er milli hámarkspolprófs og útkomu í 6 mínútna gönguprófi. ${ }^{9}$ Við upphaf meðferðar voru gerð tvö göngupróf og pað betra valið, en við lok meðferðar og í endurkomum var gert eitt próf í hvert sinn. Hreyfispurning er stöðluð spurning um líkamlega virkni síðustu prjá mánuði. ${ }^{10}$ Svarið gefur stig á bilinu 1-4, par sem stig 1 er aðallega kyrrseta, stig 2 er létt líkamleg áreynsla í minnst tvo tíma á viku, stig 3 er hreyfing með talsverðri áreynslu í að minnsta kosti tvo tíma á viku og stig 4 er stíf reglubundin pjálfun oft í viku. Við úrvinnslu gagna hér var ekki gerður munur á stigi 3 og 4 .

Eitt af skilyrðum fyrir pátttöku í hjartaendurhæfingu er að vera reyklaus eða hafa pann ásetning að verða reyklaus. Mikill stuðningur við reykleysi er veittur í meðferðinni ef pess er pörf. Spurt var um reykingar við upphaf og lok endurhæfingar og einnig í endurkomum.

Tölfræðileg úrvinnsla gagna var gerð í Microsoft Excel 2013, StatView 5.0.1, SAS Institute Inc og R. Niðurstöður eru settar fram sem meðaltöl og staðalfrávik nema annað sé tekið fram. Samanburður milli hópa var gerður með ópöruðu t-prófi fyrir samfelldar breytur en kí-kvaðrat prófi fyrir nafnabreytur. Breytingar innan hvors sjúklingahóps frá upphafi til loka meðferðar voru reiknaðar með pöruðu t-prófi. Mat á breytingum hjá rannsóknarhópnum yfir rannsóknartímann (upphaf, lok, priggja og sex mánaða eftirfylgd) var gert með dreifigreiningu (ANOVA) fyrir endurteknar mælingar fyrir samfelldar breytur en með McNemar-prófi fyrir nafnabreytur. Leiðrétt var fyrir endurteknum samanburði með Fischer post hoc-prófi. 


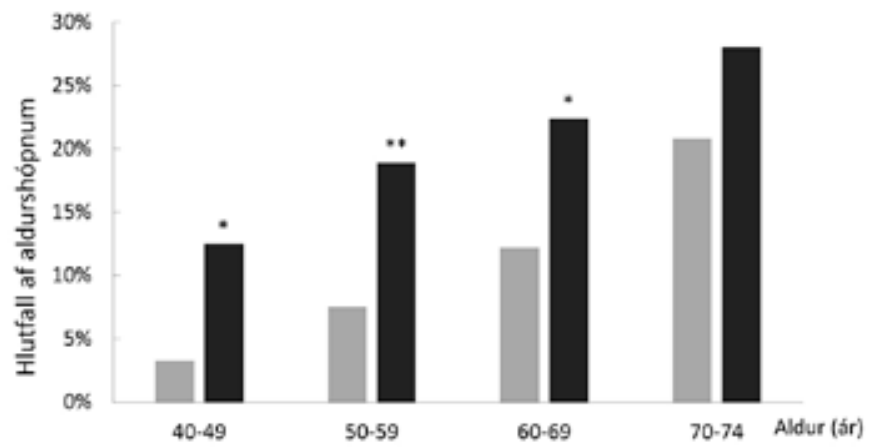

Mynd 3. Samanburður á algengi sykursýki af tegund 2 hjá körlum eftir aldurshópum, i almennu pýdi Hjartaverndar (ljósar súlur) og peirra sem koma i hjartaendurhæfingu á Reykjalundi (dökkar súlur). ${ }^{*} p<0,05 ;{ }^{* *} p<0,01$.

Rannsóknin var tilkynnt til Persónuverndar og aflað var tilskilinna leyfa frá Vísindasiðanefnd (VSNb2011040009/03.1) og framkvæmdastjóra lækninga á Reykjalundi.

\section{Niðurstödur}

Meðal peirra 292 sjúklinga sem komu til hjartaendurhæfingar á rannsóknartímabilinu voru 56, eða 19,2\%, með pekkta greiningu eða uppfylltu skilmerki um sykursýki af tegund 2.

Af 214 körlum voru 42 (19,6\%) með sykursýki af tegund 2, en 14 $(17,9 \%)$ af 78 konum. Munurinn á algengi hjá konum og körlum var ekki marktækur $(\mathrm{p}=0,87)$.

Yfirlit yfir mætingu og brottfall peirra 56 sjúklinga sem reyndust með sykursýki af tegund 2 kemur fram á mynd 2.

Algengi sykursýki af tegund 2 meðal karla og kvenna í peim sjúklingahópi sem kom til hjartaendurhæfingar var borið saman við sykursýki í almennu pýði í hóprannsókn Hjartaverndar frá sama árabili. Algengi sykursýki af tegund 2 hjá körlum á aldursbilinu 40-74 ára í hjartaendurhæfingu var 20,9\% samanborið við

Tafla I. Grunnupplýsingar um hjartasjúklinga við upphaf endurhæfingar á Reykjalundi.

\begin{tabular}{lcc}
\hline & Með sykursýki & Ekki með sykursýki \\
\hline Fjöldi, $\mathrm{n}$ & 56 & 236 \\
\hline Meðferðartími (vikur) & $4,4 \pm 0,9$ & $4,3 \pm 0,8$ \\
\hline Aldur, ár & $62,4 \pm 9,3$ & $59,6 \pm 12,5$ \\
\hline Kynjahlutfall, karlar/konur & $42 / 14$ & $172 / 64$ \\
\hline Meðferð vegna kransæðasjúkdóms, $\mathrm{n}$ & 47 & $161^{\star}$ \\
hlutfall af sjúklingahópnum, \% & 84 & $68^{\star}$ \\
\hline Meðferð vegna hjartabilunar, $\mathrm{n}$ & 2 & 12 \\
hlutfall af sjúklingahópnum, \% & 3,6 & 5,1 \\
\hline Pyngd, kg & $100,4 \pm 18,5$ & $90,3 \pm 21,4^{\star \star}$ \\
\hline LPS, kg/m² & $33,2 \pm 5,9$ & $30,0 \pm 6,5^{\star \star}$ \\
\hline Offita (LPS $\geq 30), \mathrm{n}(\%)$ & $35(63)$ & $102(43)^{\star}$ \\
\hline Mittismál, cm & $113,8 \pm 13,5$ & $104,4 \pm 17,0^{\star \star}$ \\
\hline Hámarksafköst, W & $119,6 \pm 37,1$ & $122,2 \pm 39,8$ \\
\hline Prek, W/kg & $1,20 \pm 0,29$ & $1,39 \pm 0,47^{\star \star}$ \\
\hline Fastandi s-blóðsykur, mmól/L & $6,94 \pm 1,66$ & $4,94 \pm 0,62^{\star \star}$ \\
\hline s-príglýseríð, mmól/L & $1,61 \pm 0,73$ & $1,25 \pm 0,62^{\star \star}$ \\
\hline s- HDL, mmól/L & $1,19 \pm 0,73$ & $1,25 \pm 0,35$ \\
\hline
\end{tabular}

LPS = líkamsbyngdarstuðull. Međaltöl \pm staðalfrávik;

${ }^{*} \mathrm{p}<0,05$ milli sjúklingahópa, ${ }^{* *} \mathrm{p}<0,005$ milli sjúklingahópa

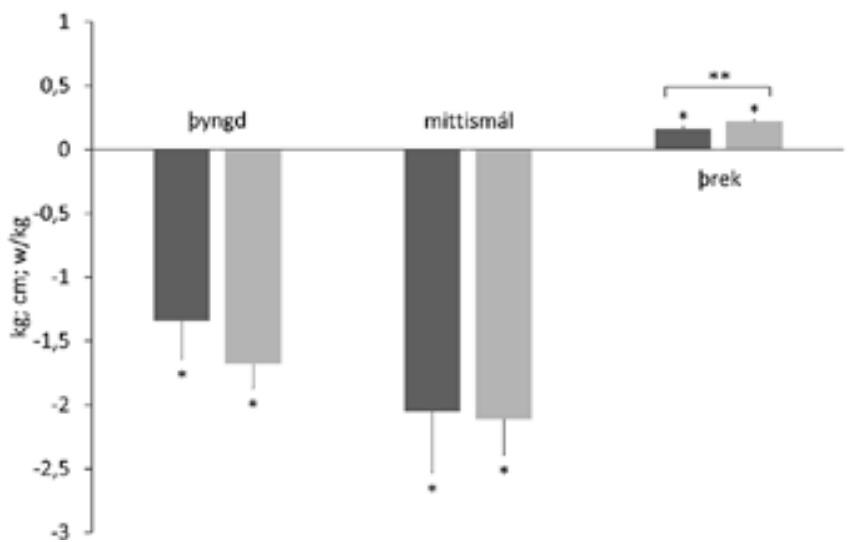

Mynd 4. Breytingar á pyngd, mittismáli og preki hjá hjartasjúklingum með sykursýki af tegund 2 (dökku súlurnar) og hjartasjúklingum sem ekki höfðu sykursýki (ljósu súlurnar) við 4 til 6 vikna endurhæfingu. Súlurnar sýna meðaltöl og staðalvillu. ${ }^{*} p<0,0001$ fyrir breytingarnar hjá hoorum hópi. ${ }^{* *} p<0,05$ samanburður á breytingum hjá sjúklingahópunum.

7,8\% í aldursstöðluðum samanburði við rannsókn Hjartaverndar $(\mathrm{p}<0,0001)$. Marktækur munur, um 2-4 faldur, var í öllum aldurshópunum nema peim elsta, 70-74 ára (mynd 3).

Meðal kvenna í hjartaendurhæfingu var tíðni sykursýki af tegund 2 einnig marktækt hærri, eða 19,7\% miðað við 3,6\% í rannsókn Hjartaverndar $(p<0,0001)$, einnig eftir að leiðrétt var fyrir aldri. Fjöldi kvenna í rannsókninni gaf ekki færi á að skoða mismuninn eftir aldurshópum.

Af 56 sjúklingum með sykursýki greindust 9 (16\%) í endurhæfingunni á Reykjalundi, en 10 (18\%) höfðu greinst innan við ári fyrir komu, 14 (25\%) höfðu haft pekkta sykursýki í 2-5 ár en 23 (41\%) í lengri tíma, 6-31 ár.

Grunnupplýsingar um hjartasjúklinga við upphaf endurhæfingar á Reykjalundi eru birtar í töflu I. Ekki var marktækur munur á aldurs- eða kynjahlutfalli hópanna. Nokkru hærra hlutfall af sjúklingum með sykursýki, eða 82\%, kom til hjartaendurhæfingar í kjölfar kransæðasjúkdóms, miðað við 64\% án sykursýki. Peir sem voru með sykursýki voru pyngri, hærra hlutfall peirra hafði offitu og mittismál var meira.

Við upphaf meðferðar var ekki munur á meðaltali hámarksafkasta í polprófi milli hópanna, en pegar tekið var tillit til líkamspyngdar reyndist prek marktækt lægra hjá peim sykursjúku. Fastandi s-glúkósi og s-príglýseríð voru hærri hjá hópnum með sykursýki, en ekki var marktækur munur á s-HDL-gildum.

Marktæk breyting varð hjá báðum hópunum á meðferðartímanum, peir léttust, mittismál minnkaði og prek jókst. Breytingin í pyngd og mittismáli var sambærileg hjá hópunum, en meðal peirra sem höfðu sykursýki varð prekaukningin aðeins minni (mynd 4). Við lok endurhæfingar var prek sykursjúkra 1,37 $\pm 0,35 \mathrm{~W} / \mathrm{kg}$, en hjá peim sem ekki voru með sykursýki 1,66 $\pm 0,54 \mathrm{~W} / \mathrm{kg}(\mathrm{p}<0,05)$.

Pað breytti engu um samanburðinn hér að ofan pótt útreikningar væru endurteknir aðeins fyrir pá sem höfðu staðfestan kransæðasjúkdóm.

Hjá hópnum með sykursýki af tegund 2 var auk pess marktæk breyting til batnaðar á fituhlutfalli og fastandi s-glúkósa í lok meðferðar (tafla II). Einnig varð marktæk aukning á genginni vegalengd á 6 mínútna gönguprófi. Við endurkomur eftir prjá og sex mánuði höfðu breytingar á pyngd, fituhlutfalli og fastandi s-glúkósa gengið til baka. Aðrar blóðrannsóknir, pað er HbA1c, 
Tafla II. Samanburður á mælingum hjá hjartasjúklingum með sykursýki af tegund 2 i endurhæfingu; við upphaf og lok meðferðar og við endurkomu eftir 3 og 6 mánuði.

\begin{tabular}{|c|c|c|c|c|}
\hline & Upphaf & Lok & Endurkoma eftir 3 mánuði & Endurkoma eftir 6 mánuði \\
\hline Fjöldi, n (\%) & $56(100)$ & $54(96)$ & $49(88)$ & $46(82)$ \\
\hline Pyngd, kg & $100,4 \pm 18,5$ & $98,5 \pm 17,6^{*}$ & $99,5 \pm 17,2$ & $99,7 \pm 17,9$ \\
\hline LPS, $\mathrm{kg} / \mathrm{m}^{2}$ & $33,2 \pm 5,9$ & $32,6 \pm 5,6^{*}$ & $32,8 \pm 5,7$ & $33,0 \pm 6,1$ \\
\hline Mittismál, cm & $113,8 \pm 13,5$ & $111,3 \pm 13,2^{*}$ & $111,2 \pm 12,4^{*}$ & $110,8 \pm 13,1^{*}$ \\
\hline Fituhlutfall, \% & $33,8 \pm 6,7$ & $33,0 \pm 7,0^{*}$ & $33,7 \pm 6,1$ & $33,7 \pm 6,5$ \\
\hline \multicolumn{5}{|l|}{6 mínútna göngupróf } \\
\hline Vegalengd, $\mathrm{m}$ & $512 \pm 96$ & $546 \pm 100^{\star}$ & $537 \pm 96^{\star}$ & $525 \pm 107^{\star}$ \\
\hline Fjöldi, $n$ & 55 & 53 & 43 & 38 \\
\hline Fastandi s-blóđsykur, mmól/L & $6,9 \pm 1,7$ & $6,3 \pm 1,1^{\star}$ & $6,8 \pm 1,5$ & $7,1 \pm 1,9$ \\
\hline $\mathrm{HbA} 1 \mathrm{c}, \%$ & $6,7 \pm 1,1$ & & $6,7 \pm 1,0$ & $6,8 \pm 1,0$ \\
\hline s-príglýseríđ, mmól/L & $1,6 \pm 0,7$ & & $1,6 \pm 0,8$ & $1,6 \pm 0,7$ \\
\hline s-HDL, mmól/L & $1,2 \pm 0,7$ & & $1,2 \pm 0,3$ & $1,2 \pm 0,4$ \\
\hline Reykingar, já/nei & $5 / 51$ & $2 / 52$ & $2 / 47$ & $1 / 45$ \\
\hline
\end{tabular}

LPS= líkamspyngdarstuðull. Meðaltöl \pm staðalfrávik. * $p<0,05$ i samanburði við mælingu í upphafi meðferðar.

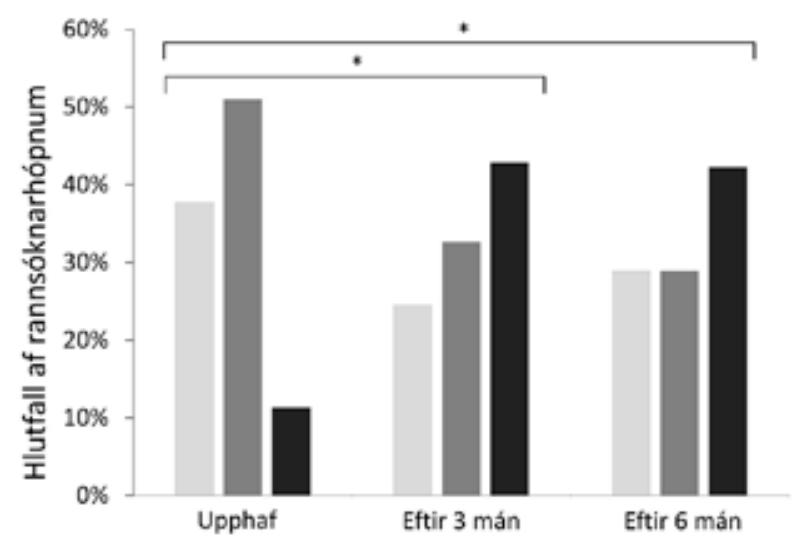

Mynd 5. Hreyfivenjur og líkamleg virkni hjartasjúklinga með sykursýki af tegund 2. Samanburður á svörum um hreyfivenjur við upphaf endurhæfingar og síðan við endurkomur 3 og 6 mánuðum eftir lok meðferðar. Hreyfing 1 (ljósgráar súlur) er aðallega kyrrseta, hreyfing 2 (milligráar súlur) er létt líkamleg áreynsla í minnst tvo tíma á viku og hreyfing 3 og 4 (dökkar súlur) er hreyfing með talsverðri eða mikilli áreynslu minnst too tíma á viku.

* $p<0,001$ i samanburði við upphaf endurhæfingar.

s-príglýseríð og s-HDL voru óbreyttar frá upphafi til loka meðferðar. Hins vegar var göngugetan áfram marktækt aukin, pó hún hafi minnkað nokkuð. Vegna ýmissa tilfallandi heilsufarsvandamála reyndist ekki unnt að taka göngupróf hjá öllum sem mættu í endurkomur.

Mikil breyting hafði orðið á hreyfivenjum og líkamlegri virkni rannsóknarhópsins frá upphafi meðferðar fram að endurkomum eftir prjá og sex mánuði. Í upphafi mátu einungis $11 \%$ hreyfingu sína í stig 3-4, en 43\% í endurkomu eftir prjá mánuði og hélst sú aukning líka eftir sex mánuði (mynd 5).

Í töflu III er sýnd lyfjameðferð við sykursýki hjá rannsóknarhópnum. Við upphaf rannsóknarinnar voru 13 sjúklingar (23\%) á insúlínmeðferð og meðalskammtur var 74 einingar á sólarhring. Fjórir pessara einstaklinga féllu úr rannsókninni, par af einn á meðferðartímanum. Ekki var hafin ný insúlínmeðferð hjá neinum sjúklingi á rannsóknartímanum. Engin tilvik urðu af alvarlegum blóðsykurföllum á meðferðartímanum.
Af peim 56 sem tóku pátt í rannsókninni höfðu margir fyrri sögu um reykingar. Fimm (9\%) reyktu enn við komu og tveir peirra voru ekki alveg hættir reykingum við útskrift. Við endurkomu eftir prjá og sex mánuði voru peir prír sem hættu reykingum enn reyklausir, en peir tveir sem reyktu við útskrift reyktu enn eftir prjá mánuði og mættu ekki eftir sex mánuði.

\section{Umræða}

Pessi rannsókn á sykursýki af tegund 2 meðal peirra sjúklinga sem komu til hjartaendurhæfingar á Reykjalundi frá júlí 2011 til desember 2012, sýndi að algengi sykursýki var miklu hærra í pessum hópi en í almennu pýði á Íslandi. Samanburður við aðra hjartasjúklinga í endurhæfingu sýndi að hópurinn með sykursýki var talsvert frábrugðinn öðrum hvað varðar pyngd, mittismál og hlutfallslega fleiri peirra voru með offitu. Ekki var marktækur munur á hámarksafköstum í polprófi við upphaf meðferðar, en prek sykursjúkra var lægra pegar tekið var tillit til líkamspyngdar. Endurhæfing rannsóknarhópsins með sykursýki gekk pó almennt vel, en báðir hóparnir, með og án sykursýki, léttust, mittismál peirra minnkaði og ekki reyndist marktækur munur á peirri breytingu á milli hópanna. Einnig bættu báðir hóparnir við sig í preki, en prek peirra sem höfðu sykursýki jókst heldur minna en annarra hjartasjúklinga.

Tafla III. Lyfjameðferð við sykursýki af tegund 2 á rannsóknartímabilinu.

\begin{tabular}{lcccc}
\hline & Upphaf & Lok & $\begin{array}{c}\text { Endurkoma } \\
\text { eftir 3 } \\
\text { mánuði }\end{array}$ & $\begin{array}{c}\text { Endurkoma } \\
\text { eftir 6 } \\
\text { mánuði }\end{array}$ \\
\hline Fjöldi, n (\%) & $56(100)$ & $54(96)$ & $49(88)$ & $46(82)$ \\
\hline Engin sykursýkislyf, \% & 12,5 & 9,3 & 8,2 & 6,5 \\
\hline Sykursýkislyf: & & & & \\
\hline Metformin, \% & 78,6 & 81,5 & 83,7 & 84,8 \\
\hline Súlfónýlúrea lyf, \% & 32,1 & 35,2 & 34,7 & 32,6 \\
\hline Önnur sykursýkislyf, \% & 7,1 & 7,4 & 8,2 & 10,9 \\
\hline Insúlínmeðferð, \% & 23,2 & 22,2 & 20,4 & 19,6 \\
\hline Insúlíneiningar & $74 \pm 49$ & $62 \pm 40$ & $61 \pm 42$ & $57 \pm 44$ \\
\hline
\end{tabular}

Athugið að samtalan í dálkunum getur verið hærri en 100\%, par sem sumir eru á fleiri en einu lyfi. 
Niðurstöður fyrri rannsókna, par sem árangur polpjálfunar hjá einstaklingum með og án sykursýki er borinn saman, eru nokkuð misvísandi. Nokkrar rannsóknir hafa komist að svipaðri niðurstöðu og hér er birt, pað er að hjartasjúklingar með sykursýki bæti árangur í preki við hjartaendurhæfingu minna en aðrir.11,12 Aðrar rannsóknir hafa fundið lægra prek í byrjun hjá sykursjúkum hjartasjúklingum eins og í pessari rannsókn, en sambærilega bætingu eftir hjartaendurhæfingu. ${ }^{13}$ Ástæður pess að hjartasjúklingum með sykursýki af tegund 2 gengur heldur verr að bæta prek sitt eru ekki að fullu pekktar, en geta til dæmis skýrst af lakara blóðflæði til vöðva í fótum. ${ }^{14}$ Einnig er pekkt röskun á starfsemi í hvatberum í pverrákóttum vöðvum sjúklinga með sykursýki af tegund $2,{ }^{15}$ sem pó virðist geta gengið til baka með pjálfun. ${ }^{16}$ Regluleg líkamleg pjálfun og hreyfing er ein af grunnstoðum meðferðar við sykursýki af tegund 2 en ýmislegt bendir til pess að peir hreyfi sig almennt minna en aðrir. ${ }^{17,18}$ Væntanlega eru pví mikil tækifæri hjá peim að ná heilsufarslegum ávinningi með aukinni hreyfingu par sem sterk rök benda til pess að regluleg hreyfing bæti heilsufar og lifun hjá peim sem hafa sykursýki af tegund 2.19,20

Niðurstöður okkar sýna að talsvert stór hluti rannsóknarhópsins jók hreyfingu og pjálfun, pví rúmlega 40\% hópsins segist í eftirfylgd hreyfa sig í að minnsta kosti tvær klukkustundir á viku af talsverðri ákefð. Petta gæti skýrt pað að bætt göngugeta sem náðist á meðferðartímanum viðhélst í eftirfylgd eftir sex mánuði.

Hjartaendurhæfing á Reykjalundi inniheldur meðal annars fjölpætta líkamlega pjálfun sem rannsóknir hafa sýnt að skilar góðum árangri í að bæta pol og styrk. Slembuð íhlutunarrannsókn á sjúklingum með sykursýki af tegund 2 sem fengu mismunandi pjálfun, sýndi aukningu í poli og styrk, en aðeins peir sem fengu blandaða styrk- og polpjálfun sýndu einnig marktæka lækkun á HbA1c miðað við samanburðarhóp. ${ }^{21}$

Aðrir pættir hjartaendurhæfingarinnar eru til dæmis fræðsla um mataræði, slökun, streitustjórnun og hvatning til aukinnar virkni og bættrar reglu á daglegum venjum, til dæmis svefnvenjum. Rannsóknir hafa sýnt að slík pverfagleg meðferð hefur góð áhrif til að draga úr einkennum um andlega vanlíðan, svo sem punglyndi og kvíða. ${ }^{22}$ Рað er mikilvæg forsenda pess að einstaklingum takist með endurhæfingu að breyta lífsháttum sínum, meðal annars að auka hreyfingu og virkni.

Ekki urðu neinar verulegar breytingar á notkun lyfja við sykursýki á rannsóknartímabilinu. Sjúklingar á insúlínmeðferð voru hvattir til að fylgjast vel með blóðsykurgildum sínum en oft er pörf á að lækka insúlínskammta eftir að pjálfunarmeðferð hefst. Engin alvarleg tilvik urðu af blóðsykurföllum eða hjartatengdum áföllum í rannsóknarhópnum á meðferðartímanum. Meðferðin virðist pví vera áhættulítil, jafnvel fyrir pennan hóp einstaklinga sem margir eru í ofpyngd og hafa í mörgum tilvikum sögu um langvarandi hreyfingarleysi auk hjartasjúkdóms og sykursýki af tegund 2.

Styrkleikar pessarar rannsóknar voru góð pátttaka, en allir sem komu til greina í rannsóknina sampykktu að taka pátt, og einnig að allvel gekk að fá pátttakendur til að mæta í eftirfylgd. Sami hópur starfsfólks sinnti meðferð sjúklinganna á rannsóknartímanum og meðferðin var vel skilgreind og samkvæmt ákveðnum ferlum. Veikleikar rannsóknarinnar felast einkum í smæð rannsóknarhópsins sem ekki leyfði samanburð innan hópsins. Einnig var talsvert brottfall í eftirfylgdinni, einkum í sex mínútna gönguprófunum. Einnig má telja til veikleika að samanburðarhópurinn kom ekki í eftirfylgdarmælingar.

Rannsókninni var fyrst og fremst ætlað að lýsa peim árangri sem næst við núverandi verklag í hjartaendurhæfingu og pví var ekki slembað í mismunandi meðferðarhópa, en ópersónugreinanleg gögn sem liggja fyrir um aðra sjúklinga í hjartaendurhæfingu voru notuð sem viðmið.

Meðal peirra sjúklinga sem komu til hjartaendurhæfingar reyndist sykursýki af tegund 2 talsvert algengari en gengur og gerist í almennu pýði. Peir sjúklingar sem hafa sykursýki eru að jafnaði pyngri og prekminni, en árangur peirra í endurhæfingu var annars að mestu sambærilegur og hjá öðrum hjartasjúklingum. Ánægjulegt var að endurhæfingin virtist skila sér í bættum daglegum venjum til lengri tíma með aukinni hreyfingu og bættri göngugetu.

Æskilegt væri að rannsaka frekar langtímaárangur hjartaendurhæfingar sykursjúkra hjá enn stærri hópi. Einnig væri áhugavert að kanna hvort öðruvísi uppbyggð endurhæfing eða virkari stuðningur eftir útskrift gæti skilað betri árangri.

\section{Pakkir}

Pakkir fær Thor Aspelund tölfræðingur fyrir aðstoð við öflun og úrvinnslu gagna frá Hjartavernd, Vísindasjóður Reykjalundar fyrir styrk til rannsóknarinnar og starfsfólk Hjartateymis Reykjalundar fyrir aðstoð við framkvæmd rannsóknarinnar. 


\section{Heimildir}

1. Zimmet PZ, Magliano DJ, Herman WH, Shaw JE. Diabetes: a 21st century challenge. Lancet Diabetes Endocrinol 2014; 2: $56-64$.

2. Thorsson B, Aspelund T, Harris T, Launer L, Gudnason V. Próun holdafars og sykursýki í 40 ár á Íslandi. Læknablaðið 2009; 95: 259-66.

3. Vilbergsson S, Sigurdsson G, Sigvaldason H, Sigfusson N. Coronary heart disease mortality amongst non-insulindependent diabetic subjects in Iceland: the independent effect of diabetes. The Reykjavik Study 17-year follow up. J Int Med 1998; 244: 309-16.

4. Huxley R, Barzi F, Woodward M. Excess risk of fatal coronary heart disease associated with diabetes in men and women: meta-analysis of 37 prospective cohort studies. BMJ 2006; 332: 73-6.

5. Association AD. Standards of medical care in diabetes 2012. Diabetes Care 2012; 35 Suppl 1: S11-63.

6. Hemmingsen B, Lund SS, Gluud C, Vaag A, Almdal T, Hemmingsen $C$, et al. Intensive glycaemic control for patients with type 2 diabetes: systematic review with meta-analysis and trial sequential analysis of randomised clinical trials. BMJ 2011; 343: d6898.

7. Embætti landlæknis; landlaeknir.is/gaedi-og-eftirlit/heilbrigdisstarfsfolk/klininskar-leidbeiningar/leidbeiningar/ item15102/Sykursyki-af-tegund-2 - október 2009.
8. Piepoli MF, Corrà U, Adamopoulos S, Benzer W, Bjarnason-Wehrens B, Cupples $\mathrm{M}$, et al. Secondary prevention in the clinical management of patients with cardiovascular diseases. Core components, standards and outcome measures for referral and delivery: a policy statement from the cardiac rehabilitation section of the European Association for Cardiovascular Prevention \& Rehabilitation. Endorsed by the Committee for Practice Guidelines of the European Society of Cardiology. Eur J Prev Cardiol 2014; 21: 664-81.

9. Hamilton DM, Haennel RG. Validity and reliability of the 6-minute walk test in a cardiac rehabilitation population. J Cardiopulm Rehabil 2000; 20: 156-64.

10. Jonsdottir IH, Rödjer L, Hadzibajramovic E, Börjesson M, Ahlborg G Jr. A prospective study of leisure-time physical activity and mental health in Swedish health care workers and social insurance officers. Prev Med 2010; 51: 373-7.

11. Toste S, Viamonte S, Barreira A, Fernandes P, Lopes Gomes J, Torres S. Cardiac rehabilitation in patients with type 2 diabetes mellitus and coronary disease: A comparative study. Rev Port Cardiol 2014; 33: 599-608.

12. Verges B, Patois-Verges B, Cohen M, Lucas B, Galland-Jos C, Casillas J. Effects of cardiac rehabilitation on exercise capacity in Type 2 diabetic patients with coronary artery disease. Diabetic Med 2004; 21: 889-95.

13. Mourot L, Boussuges A, Maunier S, Chopra S, Riviére F, Debussche X, et al. Cardiovascular rehabilitation in patients with diabetes. J Cardiopulm Rehabil Prev 2010; 30: 157-64.

14. Cosson E, Paycha F, Tellier P, Sachs RN, Ramadan A, Paries J, et al. Lower-limb vascularization in diabetic patients. Assessment by thallium-201 scanning coupled with exercise myocardial scintigraphy. Diabetes Care 2001; 24: $870-4$
15. Kelley DE, He J, Menshikova EV, Ritov VB. Dysfunction of mitochondria in human skeletal muscle in type 2 diabetes. Diabetes 2002; 1: 2944-50.

16. Hey-Mogensen M, Højlund K, Vind BF, Wang L, Dela $\mathrm{F}$, Beck-Nielsen $\mathrm{H}$, et al. Effect of physical training on mitochondrial respiration and reactive oxygen species release in skeletal muscle in patients with obesity and type 2 diabetes. Diabetologia 2010; 53: 1976-85.

17. Cichosz S, Fleischer J, Hoeyem P, Laugesen E, Poulsen P, Christiansen J, et al. Objective measurements of activity patterns in people with newly diagnosed Type 2 diabetes demonstrate a sedentary lifestyle. Diabetic Med 2013; 30: 1063-6.

18. Fagour C, Gonzalez C, Pezzino S, Florenty S, RosetteNarece $\mathrm{M}$, Gin $\mathrm{H}$, et al. Low physical activity in patients with type 2 diabetes: the role of obesity. Diabetes Metab 2013; 39: 85-7.

19. Zethelius B, Gudbjörnsdottir S, Eliasson B, Eeg-Olofsson $\mathrm{K}$, Cederholm J, Register SND. Level of physical activity associated with risk of cardiovascular diseases and mortality in patients with type-2 diabetes: report from the Swedish National Diabetes Register. Eur J Prev Cardiol 2014; 21: 244-51

20. Thomas D, Elliott E, Naughton G. Exercise for type 2 diabetes mellitus. Cochr Datab Syst Rev 2006 (3).

21. Church TS, Blair SN, Cocreham S, Johannsen N, Johnson W, Kramer K, et al. Effects of aerobic and resistance training on hemoglobin A1c levels in patients with type 2 diabetes: a randomized controlled trial. JAMA 2010; 304: 2253-62.

22. Kristiánsson K, Guðmundsdóttir Th, Jónasson MR Greining og meðferð punglyndis og kvíða sjúklinga í hjartaendurhæfingu. Læknablaðið 2007; 93: 841-5.

ENGLISH SUMMARY

\section{Effects of rehabilitation on functional capacity, obesity and health behavior, among cardiac patients with DM2}

Karl Kristjansson', Magnus R. Jonasson'1, Solrun Jonsdottir ${ }^{1}$, Hjalti Kristjansson'1, Marta Gudjonsdottir ${ }^{1,2}$

Objective: Present study examines the prevalence of type 2 diabetes (DM2) in patients attending cardiac rehabilitation (CR) compared to the general population utilising data from the Icelandic Heart Association population study. The study also examined the efficacy of CR for promoting health behaviors.

Material and methods: A prospective study among DM2 patients attending CR at Reykjalundur Rehabilitation centre. The DM2 group was compared to other cardiac patients, with respect to obesity and exercise capacity at the beginning and end of 4-6 weeks of CR. Additionally, in the DM2 group, weight, smoking cessation, physical activity and walking capacity were assessed at 3 and 6 months follow-ups.

Results: The prevalence of DM2 was 2-4 times higher in CR participants than in the general population. Compared to other CR participants, the DM2 group was heavier, with increased waist circumference and less exercise capacity. During the CR both groups lost weight and waist circumference decreased to similar extent, but the exercise capacity increased less in the DM2 group. In follow up after 6 months the DM2 group's weight and glucose values were back to same level as before $\mathrm{CR}$, but waist circumference was still decreased and they retained increased physical activity and walking capacity.

Conclusion: DM2 is more prevalent among patients in cardiac rehabilitation than in the general population. The DM2 group was more obese, had lower exercise capacity and responded somewhat less to CR than other cardiac patients. Follow up after 6 months did however show that they continued their regular exercise and walking capacity was still retained. 